\title{
The Effect of Discipline on Employees' Work Performance on the $E$ - warong KUBE PKH Program at Social Empowerment and Poor Management of the Sosial Service of Pekanbaru
}

\author{
Surya dailiati, Sri Roserdevi Nasution \\ Universitas Lancang Kuning \\ e-mail: surya-dailiati@unilak.ac.id
}

\begin{abstract}
This research aims to find out the effect of work discipline on the performance of employees on E-warong KUBE PKH at social empowerment and Poor People's Management of Pekanbaru's Sosial Department. This research is a quantitative research with an associative approach. Operational definition includes indicators and Discipline Variable (X) namely attendance, obedience to work standards, high alertness, and athical work. Then the performance variable (Y) is productivity, service quality, responsiveness, responsibility, and accountability. This research has a population of 39 people from the Office of Social Services in Pekanbaru, the sampling teachnique using the census method is the overall retrieval of the existing population. Data collection techniques used was Observation, Questionnaire and Documentation. Measurement data used is the Likert Scale. The data analysis technique used is Simple regression.Conclusions based on data analysis and testing of the resulting hypothesis, namely the influence of Discipline on the Performance of Supervisors on the E-warong KUBE PKH in the field of social empowerment and poor handling of the Social Service of Pekanbaru City obtained the results of Y $=14,576+0,722 \mathrm{x}$ and Significant $\mathrm{t}$ results of $72 \%$. Then based on the test results of the Guerdian of the E-warong KUBE PKH in the field of social empowerment and the managent of the poor, Pekanbaru social services were $55,4 \%$.
\end{abstract}

Keywords: Discipline, Performance, and E-warong KUBE PKH

Tujuan dari penelitiaan ini adalah untuk mengetahui pengaruh Disiplin terhadap Kinerja pegawai tentang E-warong KUBE PKH bidang pemberdayaan sosial dan penanggann fakir miskin Dinas sosial kota pekanbaru. Penelitiaan ini merupakan penelitiaan kuantitatif dengan pendekatan asosiatif.Defenisi operasional meliputi indikator dan variabel Disiplin $(X)$ Kemudiaan variabel kinerja (Y). Penelitiaan ini mempunyai populasi sebanyak 39 orang kantor Dinas Sosial kota Pekanbaru, teknik pengambilan sampel mengunakan metode sensus yaitu pengambilan secara keseluruhan dari jumlah populasi yang ada.Teknik pengumpulan data yang digunakan adalah Observasi, Kuesioner dan Dukumentasi.alat Pengukuran data yang digunakan adalah skala likert.Teknik analisis data yang digunakan adalah regresilinier Sederhana. Kesimpulan berdasarkan analisis data dan pengujiaan hipotesis yang dihasilkan yaitu pengaruh Disiplin terhadap Kinerja Pengawai tentang E-warong KUBE PKH bidang pemberdayaan sosial dan penanganan fakir miskin Dinas Sosial kota Pekanbaru memperoleh hasil persamaan $Y=14.574+0,722 x$ dan hasil uji Signifikan $t$ sebesar $72 \%$. Kemudiaan berdasarkan hasil uji koefisieen determinasi besar pengaruh Disiplin terhadap kinerja Pengawai tentang E-warong KUBE PKH bidang pemberdayaan sosial dan penanggann fakir miskin Dinas sosial kota pekanbaru adalah $55,4 \%$.

Kata Kunci : disiplin, kinerja, E-Warong, KUBE PKH 


\section{INTRODUCTION}

Government institution is an organization with a group of people who are particularly elected to administer the duty of nation as the service implementation for public. The aim of institution can be achieved if the government able to manage, run, and utilize the human resources efficiently and effectively.

Furthermore, it needs a human resources development for profesionalisme quality and employeess' capability improvement in implementing the job and function optimaly. Developing employees' capability aims at efficient and productive duty implementation. Thus, an organization should improve the human resources continuously because it intends to human productive capacity improvement.

Individual adaptation towards what it is stated will produce an orderly and free of violence public. Thus, the institution needs its employees' obedience to the rules and provision. In another word, employees' discipline is very crucial to achieve the goal.

Discipline presents a condition of employees' respectful to the organization's rules and provision. In other words, if the employees disobey the rules and provision, the discipline will be poor. Otherwise, work discipline is good if the employees obey and respect to the rules and provision. In conclusion, discipline is an action taken to improve the employees' attitude and behavior.

Dicipline is an individual willingness to obey all the norms and rules in an organization. A well discipline will accelerate the achievement of organization's purposes. Otherwise, a poor discipline implementation will obstacle and delay the achiement of organization's purposes. Discipline is made for managing the work not only in big companies and small companies but also for them which employees a lot of human resources.

Work dicipline is an awareness and willingness of individu to obey all the rules and norms in an organization to work maximaly. So, it needs the employees' willingness to obey all the rules and awareness of work responsibility. Besides that, the employees' attitude and behavior determines the success of dicipline implementation.

Dicipline is very important to support the organization development. It can motivate the employees to work well and educate them in obeying the rules, procedures, and policy. So, the work performance will improve.

Employees' work performance influences the organization success. It can be seen from the publics' persfective and performance evaluation. The poor performance gives the bad effects on the public services implementation because employees' work performace is one of organization success' indicators.

Work performance is also influenced by the employess' work satisfaction. It means that if the employees are satisfy on working, it will positively influence the employees' work performance improvement.

With high employees' work performance, it is expected that the effectiveness of public service implementation especialy at social and funeral Department of Pekanbaru will be achieved. It determines the readiness of facing the future changings or challenges in publics.

Social Departmen of Pekanbaru administers the government's administration in social part. It is located at jalan Datuk Setia Maharaja, Tenggerang Selatan, Harapan Raya, Kota Pekanbaru. It has three sectors as follows:

1. Sector of Protection and Social Security

2. Sector of Rehabilitation

3. Sector of Social Empowerment and Poor People Management

The improvement of government administration especially at Social Department of Pekanbaru should be able to grow the employees' work performance with aims at improving the employees' work ability maximaly because it will influence the service implementation quality. 
The structure of organization of Social Department of Pekanbaru based on the Local Regulation No. 97, 2016, is follow:

1. The Chairperson of Socail Department

2. Secretary

3. Sector of Protection and Social Security

4. Sector of Social Rehabilitation

5. Sector of Social Emporwerment and Poor Affairs

6. Unit of Department Technique Executor (UPTD)

7. Group of Functional Position

Based on the above description, the researcher focus on the Sector of Social Empowerment and Poor People Management. There are several programs of this sector such as National Healt Guarantee $(\mathrm{JKN})$, Non-Cash Food Aid (BPNT), Expectancy Family Program (PKH) and Electronik Warong Gotong Royong (E-Warong) KUBE PKH.

One of the programs such as Expectancy Family Program (PKH) above has a responsibily in improving the public prosperity in each distric. Thir program is known as E-Warong KUBE PKH of Pekanbaru.

Social ministry must implement the social protection program and poor affairs implementation by using integrated and sustainable empowerment from province government to public organization in the villages.

In fact, the poor people solving problem through social aid administration does not run well. It needs a well-organized target, budgetting, mechanisme, aid aministration, utilization and stakeholders' commitment. The former mechanisme and rules implementation cannot guarantee that the aid allocation was acceptable optimaly. So, the poor people solving problem is not integrated and sustainable.

Based on the problem above, the setting of the research is at Social Department of Pekanbaru because Social Department of Pekanbaru is one of the Departments which is empowering the social prosperity.

The researche focused on the E-Warong KUBE PKH because this program is a business and egency managed and owned by poor people who accepted the program. The information and data collected based on the work area of E-Warong KUBE PKH.

In this case, the Social minister made a policy by non-cash aid administration. To realize it, a business facility development aid through Elektronik Warung Gotong Royong Kelompok Usaha Bersama Program Keluarga Harapan (E-Warong KUBE-PKH) was made. The philosophy of this program is mutual cooperation business group.

E-Warong KUBE PKH is a fcility of business founded by mutual cooperation business group $(K U B E)$ in service sector as a non-cash aid facility administration in form of foodstuffs and electornic money, business interest, and product marketing.

E-Warong KUBE PKH offers four services. They are non-cash social aid administration such as electronic foodstuffs, public needs, and product marketing and social aid withdrawal.

Non-casch aid administration such as electronic foodstuffs contains of rice, cooking oil, wheat flour, and sugar. The supply of the stuffs done by social ministry through Perum Bulog or the agent which supply the staff. In this transaction, the price had been stated and can be paid by using in-cash electronic transaction. There are several requirements for being the members of $e$-Warong KUBE PKH:

1. The aid recipient of $U E P K U B E$ of social ministry

2. The recipient of $P K H$

3. The recipient of Rastra Program

4. 500 to 1000 members of $K K / K P M$ 
There are 29 of developing E-warong KUBE PKH in Pekanbaru. E-warong KUBE PKH facilitates the public in foodstuffs fulfillment such as rice for Rastra and PKH. It is planned that the development of E-warong KUBE will be implemented in districts. One of E-warong KUBE-PKH of Pekanbaru is E-Warong Rumbai Sejahtera in Rumbai.

E-Warong Rumbai Sejahtera in Rumbai is less developed because the employees' performance is poor. There are almost of emloyees use the work time for personal interests. So, it makes the quality of service implementation becomes poor. It determines the lack of responsibility of employees in working.

Based on the observation result of Social Department Employees' dicipline, it was found some phenomenon related to the lack of E-Warong KUBE PKH employees' attendance. This following table presents the data about it.

Tabel 1. Attendance of $E$-warong Rumbai Sejahtera Employees in 2018

\begin{tabular}{llcccccc}
\hline \multirow{2}{*}{ No } & \multirow{2}{*}{ Month } & $\begin{array}{c}\text { Employee's } \\
\text { Number }\end{array}$ & \multirow{2}{*}{ Weekdays } & \multicolumn{3}{c}{ Attendance } & \multirow{2}{*}{$\begin{array}{c}\text { Numbers of } \\
\text { Attendance }\end{array}$} \\
\cline { 5 - 7 } 1 & January & 10 & 26 & 24 & 11 & 9 & 44 \\
\hline 2 & February & 10 & 23 & 22 & 13 & 10 & 45 \\
\hline 3 & March & 10 & 26 & 20 & 8 & 11 & 39 \\
\hline 4 & April & 10 & 24 & 18 & 7 & 5 & 30 \\
\hline 5 & May & 10 & 24 & 14 & 9 & 7 & 30 \\
\hline 6 & June & 10 & 18 & 21 & 6 & 5 & 32 \\
\hline 7 & July & 10 & 22 & 15 & 9 & 6 & 30 \\
\hline 8 & August & 10 & 28 & 22 & 7 & 8 & 37 \\
\hline 9 & September & 10 & 24 & 13 & 8 & 10 & 41 \\
\hline 10 & October & 10 & 22 & 10 & 9 & 7 & 26 \\
\hline 11 & November & 10 & 22 & 13 & 8 & 10 & 31 \\
\hline 12 & December & 10 & 20 & 17 & 7 & 6 & 30 \\
\hline
\end{tabular}

Source: Social Department of Pekanbaru, 2019

From the above table, it can be seen the employees' attendance is not optimal. So, the employees of social department is inactive in implementing the service of E-warong KUBE $P K H$. It can be concluded that the dicipline and attitude of E-warong $K U B E P K H$ members is not maximal.

$E$-Warong KUBE PKH states that the public should have qualified access for all information and decision making process. So, the economic activity management will be productive.

The particular problem to solve relates to the E-warong benefit. Thee poor people who receive this aid do not know well about it. Besides that, they do not have any ideas about financing and payment system of E-Warong. This payment will automaticaly connect to social ministry information system. That is why it needs qualified human resouces with capability of management information system and financial management implementation.

There were several training had been given to the E-Warong Rumbai Sejahtera. These training related to the accuracy in working, utilize facility efficiently and effectively, using technology training, stock management training, and writing the financial report training.

Based on data collected, there was no tutor able to give a training related to productive business and creative economy business development. As the way out, E-warong collaborate with Kamar Dagang Industry (KADIM) will train the members or employees of E-warong. It is also expected that Social Department of Pekanbaru increase the monitoring activity to E-warong KUBE PKH in Pekanbaru.

E-Warong KUBE PKH supplies the daily needs such as rice, eggs, soaps, cooking oil, sugar, wheat flour, etc. Unfortunately, the social department of Pekanbaru distribute the aid as much as Rp. 
20.000.000., in once. In fact, the stocks is unavailable in E-Warong KUBE PKH because the lack of budget.

Based on the description above, there were several phenomenon as follows:

1. E-Warong KUBE PKH has 10 members. Based on the data, there are only 5 active members. It makes the program does not run maximal.

2. E-Warong KUBE $P K H$ has several training programs. They are utilizing information technology training, management stock training, and writing the financial report training. But, the less of training from Social Department of Pekanbaru and the lack of tutor for training.

3. Social Department of Pekanbaru gives social aid through E-Warong KUBE PKH about Rp. 20.000.000., for business and working. In fact, there is a less stock of rice, eggs, sugar, flour, cooking oil, etc. It influences the employees' performance of E-Warong KUBE PKH.

\section{METHOD}

The data was collected by using questionnaire. It is used to see the hypothesis between independent variable and dependent variable. The data was analized by using quantitative analysis. Data analysis in this research used stastistical analysis and simple linear regression. Simple linear regression is used to see the amount of influence of independent variable partially toward the dependent variable.

\section{FINDING AND DISCUSSION}

\section{Validity Test}

Validity is an indication of how sound your research is. More specifically, validity applies to both the design and the method of your research. Validity in data collection means that the finding truly represents the phenomenon.

Validity test is used to know the appropriateness of every statement in defining the variable. It supports a group of particular variable. Sujarweni (2015: 19) states that validity test should be done in every statement. $R_{\text {hitung }}$ result is compared to $r_{\text {table }}$ in which $d f=n-2$ with significant $5 \%$. If $r_{\text {tabel }}<r_{\text {hitung }}$, it is valid. Sugiono (2008) says that validity test is used by using Product Moment correlation. If the validity coefficient $\left(r_{\text {hiitung }}\right)>$ validity coefficient $\left(r_{\text {table }}\right)$, it means that the instrument is valid. It is not valid if the validity coefficient $\left(\mathrm{r}_{\text {hitung }}\right)<$ validity coefficient $\left(\mathrm{r}_{\text {table }}\right)$.

This following table presents the validity test of each questionnaire item of the discipline and work performance variable.

Tabel 2. Validity Test Item of Work Dicipline

\begin{tabular}{lccc}
\hline No & $\begin{array}{c}\text { Validity Coefficient } \\
\mathbf{r}_{\text {hitung }}\end{array}$ & $\begin{array}{c}\text { Validity Coefficient } \\
\mathbf{r}_{\text {tabel }}\end{array}$ & Status \\
\hline 1 & 0,316 & & Valid \\
\hline 2 & 0,415 & & Valid \\
\hline 3 & 0,651 & & Valid \\
\hline 4 & 0,447 & & Valid \\
\hline 5 & 0.379 & & Valid \\
\hline 6 & 0,457 & & 0,271 \\
\hline 7 & 0,591 & & Valid \\
\hline 8 & 0,277 & & Valid \\
\hline 9 & 0,638 & & Valid \\
\hline
\end{tabular}




\begin{tabular}{lll}
\hline 10 & 0,303 & \\
\hline 11 & 0,473 & Valid \\
\hline 12 & 0,362 & Valid \\
\hline 13 & 0,379 & Valid \\
\hline 14 & 0,388 & Valid \\
\hline
\end{tabular}

Source: SPSS Data Analysis

From the above table, it can be seen that the each item of the questionnaire for work discipline variable has coefficient value $\left(\mathrm{r}_{\text {hitung }}\right)>\left(\mathrm{r}_{\text {tabel }}\right)$. It means that every item of the questionnaire for discipline work variable is valid. So, it can be used as the indicator and can be analyzed.

The table below will present the result of validity test of Work Performance variable.

Tabel 3. Validity Test of Work Perfomance Variable

\begin{tabular}{lccc}
\hline No & $\begin{array}{c}\text { Validity Coefficient } \\
\mathbf{r}_{\text {hitung }}\end{array}$ & $\begin{array}{c}\text { Validity Coefficient } \\
\mathbf{r}_{\text {tabel }}\end{array}$ & Status \\
\hline 1 & 0,601 & & Valid \\
\hline 2 & 0,552 & & Valid \\
\hline 3 & 0,498 & & Valid \\
\hline 4 & 0,456 & & Valid \\
\hline 5 & 0,644 & & Valid \\
\hline 6 & 0,427 & 0,271 & Valid \\
\hline 7 & 0,702 & & Valid \\
\hline 8 & 0,472 & & Valid \\
\hline 9 & 0,748 & & Valid \\
\hline 10 & 0,494 & & Valid \\
\hline 11 & 0,570 & & Valid \\
\hline 12 & 0434, & & Valid \\
\hline 13 & 0,537 & & Valid \\
\hline 14 & 0,658 & & Valid \\
\hline 15 & 0,663 & & Valid \\
\hline
\end{tabular}

Source: SPSS Data Analysis

Based on the table above, it can be concluded that every item of the statements for work performance variable has coefficient value $\left(\mathrm{r}_{\text {hitung }}\right)>\left(\mathrm{r}_{\text {table }}\right)$. It means that every item is valid as the indicator of the variable and can be analyzed.

\section{Reliability Test}

Reliability concerns the extent to which any measuring procedure yields the same results on repeated trials. The reliable questionnaire can be used as the instrument for a research. For determining the realibility, Cronbach Alpha method is used. An instrument is valid if the Cronbach Alpha value is $\geq$ 0.60. It is not reliable if the Cronbach Alpha value is < 0,60 (Sekaran, 2006).

Tabel 4. Reliability Test

\begin{tabular}{|c|c|c|c|c|}
\hline No & Variable & $\begin{array}{c}\text { Cronbach } \\
\text { Alpha }\end{array}$ & Alpha Tbel & Status \\
\hline 1 & Work Dicipline & 0,812 & \multirow[t]{2}{*}{0,600} & Reliable \\
\hline 2 & Work Performance & 0,891 & & Reliable \\
\hline
\end{tabular}

Source: SPSS Data Analysis 
Based on the table above, it can be seen that all the variable of the research has Cronbach Alpha Correlation Coefficient > 0.60. It means that all the variables are reliable and can be used.

\section{Normality Test}

Normality test used for measuring wheter the data normaly distributed so can be used in statistical parametric. It is caused by the parametric tests is made from the normal distribution. It aims at knowing the data distribution in variable of the research. According to Wiranta (2015), the qualified data in a research is a data with normal distribution. Normality data can be analyzed by using KolmogorovSmirnov normality test. If $\mathrm{p}>0,05$, it means that the distribution is normal.

This test used to find out wheter the distribution of the data is based on the normal curve distribution. The result of the normality test of the work discipline variable is $\mathrm{Z}=0.614, p=0,846(p>$ $0,05)$. It means that there is no significant different between empirical frequency and the theoretical curve. It can be concluded that the data is distributed normaly.

The result of the normality test of work performance variable is $\mathrm{Z}=0.704, p=0,704(p>0,05)$. It means that there is no significant different between empirical frequency and the theoretical curve. It can be concluded that the data is distributed normaly.

Table 5. Normality Test

One-Sample Kolmogorov-Smirnov Test

\begin{tabular}{llrr}
\hline & & $\begin{array}{c}\text { Work } \\
\text { Dicipline }\end{array}$ & $\begin{array}{c}\text { Work } \\
\text { Performance }\end{array}$ \\
\hline $\mathrm{N}$ & & 39 & 39 \\
Normal Parameters $^{\mathrm{a}}$ & Mean & 47.03 & 48.51 \\
& Std. Deviation & 7.453 & 9.038 \\
Most Extreme & Absolute & .098 & .113 \\
Differences & Positive & .098 & .076 \\
& Negative & -.081 & -.113 \\
Kolmogorov-Smirnov Z & .614 & .704 \\
Asymp. Sig. (2-tailed) & .846 & .704 \\
\hline
\end{tabular}

a. Test distribution is Normal.

\section{Linearity Test}

Linearity test aims at finding out the linear correlation between the independent and dependent variables. Linearity test uses rule of significance $(p)$ from $\mathrm{F}$ value (Deviation form linearity) $>0.05$, so the correlation between two variables is linear. But, if the significance $(p)$ from $\mathrm{F}$ value (Deviation form linearity) $<0.05$, the correlation between two variables is not linear. The indicator of linearity test uses significant $5 \%$.

Basedon the linearity test result for work discipline and work performance, it was found that $\mathrm{F}$ value (Deviation from Linearity) is $>0.94$ with $p=0.580(p>0.05)$. It means that the linear correlation between two variables is linear. 


\begin{tabular}{|c|c|c|c|c|c|c|c|}
\hline \multicolumn{8}{|c|}{$\begin{array}{c}\text { Tale 6. Linearity Test } \\
\text { ANOVA Table }\end{array}$} \\
\hline & & & $\begin{array}{l}\text { Sum of } \\
\text { Squares }\end{array}$ & df & $\begin{array}{l}\text { Mean } \\
\text { Square }\end{array}$ & $\mathrm{F}$ & Sig. \\
\hline \multirow{6}{*}{$\begin{array}{l}\text { Kinerja * } \\
\text { DisiplinKerj } \\
\text { a }\end{array}$} & Between & (Combined) & 1970.24 & 18 & 109.458 & 1.931 & .078 \\
\hline & Groups & & 4 & & & & \\
\hline & & Linearity & $\begin{array}{r}1099.49 \\
9\end{array}$ & 1 & $\begin{array}{r}1099.49 \\
9\end{array}$ & $\begin{array}{r}19.40 \\
0\end{array}$ & .000 \\
\hline & & $\begin{array}{l}\text { Deviation } \\
\text { from } \\
\text { Linearity } \\
\end{array}$ & 870.745 & 17 & 51.220 & .904 & .580 \\
\hline & Within C & oups & $\begin{array}{r}1133.50 \\
0\end{array}$ & 20 & 56.675 & & \\
\hline & Total & & $\begin{array}{r}3103.74 \\
4\end{array}$ & 38 & & & \\
\hline
\end{tabular}

\section{Hyphotesis Test}

The hyphotesis of this research is there is a correlation between work discipline and work performace of social department of Pekanbaru. So, a simple linear regression analysis is conducted by using t-test.

T-test used for testing the significant regression (b), it is work diciplin (X) as the independent variable affect significantly or not towards the work performance $(Y)$ as the dependent variable. In the hypothesis test, the writer have got the value of trustworthiness in the amount of $95 \%$ with $\alpha=0,05$.

\section{Simple Linear Regression Analysis}

It is used for finding out wheter it is a significant effect or not of the dependent variable, how is the effect (positive or negative), the amount the effect, and to predict the dependent variable value by using independent variable.

The result of simple linear regression analysis found that every single independent variable (X) has affected significantly the dependent variable (Y). It can be seen in the following table.

\section{Table 7. Simple Linear Regression Test}

Coefficients $^{\mathrm{a}}$

\begin{tabular}{|c|c|c|c|c|c|}
\hline \multirow[b]{2}{*}{ Model } & \multicolumn{2}{|c|}{$\begin{array}{l}\text { Unstandardized } \\
\text { Coefficients }\end{array}$} & \multirow{2}{*}{$\begin{array}{l}\text { Standardized } \\
\text { Coefficients } \\
\text { Beta }\end{array}$} & \multirow[b]{2}{*}{$\mathrm{T}$} & \multirow[b]{2}{*}{ Sig. } \\
\hline & $\mathrm{B}$ & Std. Error & & & \\
\hline (Constant) & 14.574 & 7.625 & & 1.912 & .064 \\
\hline $\begin{array}{l}\text { DisiplinKerj } \\
\text { a }\end{array}$ & .722 & .160 & .595 & 4.505 & .000 \\
\hline
\end{tabular}

a. Dependent Variable: Work Performance

From the table above, it can be seen that the a value is 14.574 . It means that if there is no data changing of work discipline (independent variable), the work performance $c=$ value is about 14.574 as the constant value of dependent variable. In addition, $b$ value is about 0.722 . It means that every enhancement of work discipline as well as 0.722 , there will be an enhancement of the work performace about 1 level. 
The hypothesis of this research is "there is a significant effect of work discipline towards the employees' work performance of E-warong KUBE PKH Program at Social Department of Pekanbaru". The result of multiple linear analysis data tells that regression coefficient value of work discipline $(\mathrm{X})$ is about 0.722 .

Siginificant value of work discipline is about 0.000 if the significant value is compared to the significant level used in this research which is $\alpha=0,05$, it proved that the significant value is lower than significant level used $(0,000<0,05)$. It means that there is a significant effect between work discipline and work performance of E-warong KUBE PKH Program at Social Department of Pekanbaru. Thus, the hypothesis offered is accepted with truthworthiness level of $95 \%$.

Furthermore, the higher work discipline of employees, the higher work performance they have. In another word, if the government wants to improve the employees' work performance, it should be a wellorganized evaluation to the employees' work discipline.

\section{T test}

T-test used to identify wheter the work discipline affects significantly towards the work performance. The test uses significancy level 0.05 . Because the value of $t_{\text {hitung }}>t$ tabel $(4.505>1.68709)$ and significancy $<0,05(0,000<0,05)$. It can be described that the hypothesis stated is accepted. It is concluded that the work discipline significantly affect the employees' work performance.

\section{Coeffiecient of Determination $\left(\mathbf{R}^{2}\right)$}

To identify the value of independent variable contribution towards the dependent variable, it is used the value of $\mathrm{R}_{\text {squared }}$ of the output Model summary $(b)$ as follows.

Table 8. The Result of Coefficient Determination of X1-Y Model Summary

\begin{tabular}{llrrr}
\hline Model & R & R Square & $\begin{array}{c}\text { Adjusted R } \\
\text { Square }\end{array}$ & $\begin{array}{l}\text { Std. Error of } \\
\text { the Estimate }\end{array}$ \\
\hline 1 & $.795^{\mathrm{a}}$ & .554 & .537 & 5.360 \\
\hline
\end{tabular}

a. Predictors: (Constant), Work Dicipline

Based on the above table, it is found that the value of $\mathrm{R}_{\text {squared }}$ is about 0,554. It describes the contribution value of independent variable $(\mathrm{X})$ to dependent variable $(\mathrm{Y})$. This value shows that the effective contribution of work discipline is about 55.4\%. It is affected by other excluded variables.

Based on the data analysis, it can be concluded that there is a positif correlation between work discipline and employees' work performance. Based on the $t$-test, the value of $t_{\text {hitung }}>t_{\text {tabel }}$, it is 4,505 $>1.68709$. It means that work discipline significantly affect the employees' work performance of social department of Pekanbaru. Then, based on the coefficient determination $\left(\mathrm{R}_{2}\right)$, it can be seen that work discipline affects as much as $35.4 \%$ towards the employees' work performance improvement.

The finding of the research describes that work discipline has significant positive effect towards the employees' work performance. Furthermore, if the employees have good work discipline, their work performance will improve.

This finding is supported by the theory proposed by Rivai and Sagala in Nurmansyah (2016:215), they say that discipline has an effect to the employees' work performance. In line with it, Simanjutak in Nurmansyah (2016:215) states that an employe's work performance is affected by competence, work discipline, ethic, motivation, work environment, facility and technology, and leadership.

Based on the theory proposed, it can be concluded that discipline is employee's attitude, behavior, and action towards his responsibility and ability in running all the rules stated by the organization (Nurmansyah, 2016:215). 
Hhypothesis is accepted if the value of $t_{\text {hitung }}>t_{\text {tabel }}$ and value of $\operatorname{sig}<\alpha 0,05$. Value of $t_{\text {tabel }}$ at $\alpha$ 0,05 is 1,68709 . For work discipline variable $(\mathrm{X})$ value of $t_{\text {hitung }}$ is 4,505 and value of significancy is 0,000 . Furthermore, it can be said that $\mathrm{t}_{\text {hitung }}>\mathrm{t}_{\text {tabel }}$ is $4.505>1,68709$ and value of significancy is $0,000<$ 0,05 . It can be proved that work discipline $(\mathrm{X})$ has significant effect towards the employees' work performance. So, the hypothesis is accepted.

Then, a research of Ninik Srijani (2017) entitiled the effect of work performance towards the employees' work performance at Sambel Pecel Wahyu Tumurun Factory in Madiun states that work discipline has a correlation and effect to employees' work performance. Thus, if work discipline is applied in the factory, it will create a good employees' work performance.

A research donducted by Devy (2017) entitled the work discipline effect towards the employees' work performance of trade and industry department, cooperative and small and medium scale industry of Samarinda, East Kalimantan Province. The independent variable is work discipline and dependent variable is employees' work performance. The finding of the research describes that work discipline has a significant effect towards the employees' work performance.

Then, a research conducted by Aldo (2017) entitled the effect of discipline to employees' work performance of Library and Archives Agency of Riau Island Province. The independent variable is discipline and independent variable is employees' work performance. It was found that work discipline has a significant effect towards the employees' work performance of Library and Archives Agency of Riau Island Province.

The last is a research conducted by Devi and Isma (2016) entitled the effect of work discipline towards the employees' work performance of PT. Perkebunan Nusantara XI, Pangottan Sugar Factory, Madiun. The independent variable is discipline and independent variable is employees' work performance. It was found that work discipline has a significant effect towards the employees' work performance of Pangottan Sugar Factory, Madiun.

\section{CONCLUSION}

Based on the findings, it can be concluded that:

a. All indicators of work discipline variable are fair. It can be seen from the data analysis result. It was found that the employees' attendance is poor. Based on the interview result from public or visitors, it can be identified that the employees' discipline is poor.

b. The employees' of E-Warong KUBE PKH had lack of consistency in running the job and responsibility. Based on the interview result from public or visitors, it can be identified that the employees' work performance is poor.

c. Based on the data analysis result using simple regression linear, the coefficient determination ( $R$ Square) is $55.4 \%$. It can be concluded that work discipline has affect $55.4 \%$ towards the employees' work performance of social department of Pekanbaru. Based on the t-test, it was found that the value of $t_{\text {hitung }}>t_{\text {tabel }}$ is 4,505 $>1,68709$. It means that work discipline has a significant effect towards the employees' work performance improvement

\section{SUGGESTION}

1. E-Warong $K U B E P K H$ does not optimaly run yet. Therefore, it needs an improvement especialy the work time of employees and the attendance of employees.

2. The improvement of work discipline of E-Warong KUBE PKH of social department of Pekanbaru should be followed by the monitoring and evaluation program. 
3. Social department of Pekanbaru should give scheduled and continuous education and training to the employees' of E-warong KUBE PKH for improving their knowledge of work responsibility and job descriptpion.

\section{BIBLIOGRAPHY}

[1]. Ali, Faried. 2013. Teori dan Konsep Adm. Jakarta. RajaWali Pers.

[2]. Badrulin. 2014. Dasar-Dasar Manajemen. Bandung. Alfabeta.

[3]. Priyatno,Duwi. 2018 . SPSS Panduaan Mudah Olah Data Bagi Mahasiswa \& umum . Yogyakarta. Andi Offset.

[4]. Devy, D.S. 2017 Pengaruh Disiplin Kerja terhadap kinerja pegawai pada Dinas Perindustriaan Perdangangan,Koperasi,dan Usaha Mikro Kecil dan Menengah Provinsi Kalimantan Timur Samarinda. e.Journal Administrasi Bisnis. V (1), 104-105.

[5]. Devi \& isma,W.2016 Pengaruh Disiplin kerja terhadap kinerja kariawan pada PT.Perkebunan Nusantara XI persero Pabrik Gula Pangottan Madium.e.Journal Administrasi Bisnis.V(1),195-196.

[6]. Hadi. 2013. Metode Penelitiaan Administrasi Publik. Bandung. Alfabeta.

[7]. Kurniawan, Saefullah. 2015. Pengantar Manajemen. Jakarta. Kencana.

[8]. Leonard. 2012. Teori Administrasi publik. Bandung. Alfabeta.

[9]. Mulyono. 2015. Manajemen Administrasi dan Organisasi Pendidikan. Jogjakarta. Ar-Ruzz Media.

[10]. Nawawi . 2013. Metode Penelitiaan Administrasi Publuk. Bandung. Alfabeta.

[11]. Srijani, N. (2014). Pengaruh Disiplin Kerja Terhadap Kinerja Karyawan Pada Industri Sambel Pecel Wahyu Tumurun Madiun. Equilibrium: Jurnal Ilmiah Ekonomi Dan Pembelajarannya, 2(1).

[12]. Nurmansyah. 2010. Manajemen Sumber Daya Strategi. Pekanbaru. perpustakaan Nasional.

[13]. Nurmansyah. 2016. perilaku organisasi.Rumbai Pekanbaru. Unilak Press.

[14]. Pasolong, Harbani. 2011. Teori administrasi Publik. Bandung. Alfabeta.

[15]. Pasolong, Harbani 2013.Metode penelitian Administrasi Publik. Bandung. Alfabeta.

[16]. Rosady, Ruslan. 2016. Manajemen Publik Relations dan Media Komunikasi. Jakarta. RajaGrafindo Persada

[17]. Saputra, T., \& Herianto, M. (2014). Komitmen organisasi, keadilan organisasi, dan kualitas pelayanan. Jurnal Administrasi Pembangunan, 2(2), 127-134. 
[18]. Saputra, T. (2016). Pengaruh Motivasi Kerja Terhadap Disiplin Kerja Pegawai Pada Dinas Pemuda Dan Olahraga Provinsi Riau. Jurnal Niara, 8(2), 50-60.

[19]. Sinambela, Lijan Poltak. 2017. Sumber Daya Manusia. Jakarta . Bumi Aksara.

[20]. Sinambela, Lijan Poltak .2017. Manajemen Sumber Daya Manusia. Jakarta Bumi Aksara.

[21]. Sugiono. 2013. Metode Penelitiaan Administrasi Publik. Bandung. CV.Alfabeta.

[22]. Sutrisno, Edy2009. Manajemen Sumber Daya Manusia. Jakarta. PT,Kencana Media Group

[23]. Sujarweni, Wiratna. 2015. SPSS Untuk Penelitiaan. Yogyakarta. Pustaka baru Press.

[24]. Syafiie, I. K. Motivasi Pegawai Pada Badan Kepegawaian Daerah Kabupaten Kuantan Singingi." NURPENI Universitas Lancang Kuning, Jl. DI Pandjaitan Km 8 Pekanbaru E-Mail: Pennymuryanto@ Yahoo. Co. Id.

[25]. Wibowo. 2014. Manajemen Kinerja. Jakarta. Raja Grafindo Persada. 